\title{
Productivity of Gears in Seasonal Floodplain Fishing: Case Study on Sholiamary and Gheramary Beels in Mymensingh, Bangladesh
}

\author{
Md Istiaque Hossain* \\ Associate Professor \\ Department of Fisheries, Faculty of Agriculture \\ University of Rajshahi \\ Rajshahi, Bangladesh \\ Mobile: +8801726514232 \\ Email: bitanrubd@yahoo.com, bitan@ru.ac.bd \\ Md. Mahmudul Alam \\ PhD Student \\ Institute for Environment and Development (LESTARI) \\ National University of Malaysia (UKM) \\ Selangor, Malaysia \\ Cell: +60162799091 \\ Email: rony000@gmail.com \\ Madan Mohan Dey \\ Professor \\ Aquaculture Economics and Marketing \\ Aquaculture/Fisheries Center \\ University of Arkansas Pine Bluff, USA \\ Tel: +18705758108 \\ E-mail: $\underline{\text { mdey@uaex.edu }}$ \\ * Corresponding author
}

\section{Citation Reference:}

Hossain, M.I., Alam, M.M., Dey, M.M., Siwar, C., and Mokhtar, M.B. 2014. Productivity of Gears in Seasonal Floodplain Fishing: Case Study on Sholiamary and Gheramary Beels in Mymensingh, Bangladesh. Nova Journal of Humanities and Social Sciences, Vol. 2(2). pp. 1-20. [Online Link]

This is a pre-publication copy.

The published article is copyrighted by the publisher of the journal. 


\title{
Productivity of Gears in Seasonal Floodplain Fishing: Case Study on Sholiamary and Gheramary Beels in Mymensingh, Bangladesh
}

\begin{abstract}
Bangladesh is the largest floodplain land of the world, which constitutes $80 \%$ land areas and $73 \%$ of households of the country. In the floodplain beel area, there are three types of fishermen - part-time, full-time, and subsistence - who mostly depend on the fishing in the monsoon time. However, due to environmental degradation and over exploitation of resources the fish production in these beels has dropped down significantly. Therefore, to ensure the efficient ways of harvesting and to ensure the socioeconomic welfare of the fishermen, understanding the nature and efficiency of available gears is very important. To measure the productivity of locally used gears this study collected primary data from the beel Sholiamary and beel Gheramary areas from Mymensingh Sadar in Bangladesh through a questionnaire survey based on simple stratified random sampling method. The data were analyzed though descriptive statistics, percentile analysis, one-way analysis of variance (ANOVA) F-test, Post Hoc (Scheffe) test, and Pearson's correlation test. The statistical tests were measured at 1\%,5\%, and 10\% significance levels. This study concluded that the physical productivity in terms of daily catches and economic productivity in terms of income from fishing differed significantly among the available gears - five fishing nets, one fishing trap and two wounding gears. The highest number of used gears was wounding, and the lowest one was seine-net. The highest fishing effort and fishing duration were recorded for bair, and lowest fishing effort was for seine-net and lowest fishing duration was for push-net. However based on catch per unit of effort the seine-net was found the most productive gear and the bair was the least productive gear. In terms of monetary return (TK), gill-net and long-line provided the highest value and bair the lowest.
\end{abstract}

Key words: Social, economic, productivity, floodplain, beel, gear, fisherman

\section{Introduction}

Bangladesh is blessed with having the world's largest river delta. The geographic location of the country is at the delta of three river systems - Ganghes, Brahmaputra and Meghna. Thus fishing is one of the important sub-sectors of Bangladeshi economy, which contributes $4.07 \%$ to the total GDP and 22\% to the agricultural GDP in year 2005-2006. Fisheries sector employs about 1.3 million full time fisher men and 12.5 million part time fishermen whose number peak in June to October during flood season (DoF 2008).

Every year during rainy season, (July-September) huge volume of water make way into the country on its way to the Bay of Bengal and about $90 \%$ of annual rainfall occurs at this time. That leads to occurrences of flood and submersion of the country's low lands for 4 to 6 months. Therefore, Bangladesh is said to be the world's largest floodplain with $80 \%$ floodplain land area. A number of different habitats occur within the Bangladesh floodplains. These include the river itself, canals and permanent and semi- 
permanent standing water bodies (beels and Haors). According to Master Plan Organization (MPO) 1986, the net cultivable area of Bangladesh is 9,562,402 hectare (ha), out of which $6,30,0723$ ha are floodplains and vulnerable to annual submersion to different depth.

These seasonal floodplains are being utilized for crop production, fishing and for collecting other aquatic resources such as snails, aquatic plants, etc. The Bangladesh Department of Fisheries estimated that $73 \%$ of all households are involved in floodplain fisheries (DOF 1990) and they catch either for income or for food (Minkin et al. 1997; Thompson et al. 1999). The full time fishermen living around the seasonally flooded areas are the poorest and landless social group. Majority of the part time and subsistence fishers are small scale paddy cultivators, though some influential rich are also involved in part time fishing activities.

Due to the dependency on open access fisheries, an exploitation of the fishing resources has been observed (Ahmed et al.1992; Siddiqui 1989). Erection of flood control embankments, wide spread use of insecticides and pesticides, water pollution, siltation of rivers, lack of policy for managing these waterbodies have attributed to the decline of fish availability. The contribution of inland open waters to total fish production has decreased from $63 \%$ in $1983-1984$ to $36 \%$ in $2002-2003$ (DOF 2004).

In floodplain beels of Bangladesh, fish production has dropped down to 50-55\% due to environmental degradation which includes human interventions through construction of flood control embankments, drainage system and sluice gates, conversion of inundated land to crop land-thereby reducing water area and indiscriminate use of pesticides and insecticides, pollution from domestic, industrial and agro-chemical wastes and run-off have resulted in causing extinction of a considerable amount of an aquatic biota in some stretches of the open water system (Mazid \& Hossain 1995). Hoque (1995) mentioned that fish diversity is also decreasing. There are now 13 critically endangered, 28 endangered and 14 vulnerable fish species out of a total of 296 freshwater/brackish fish species existing in Bangladesh.

Sadeque (1992) pointed out resource use, conflict, improper infrastructure, and lack of restocking, indiscriminate pesticide use and over fishing as the causes of this decline. Ali et al. (1995) noted that apart from the disruption of the natural cycle of fish migration, reproduction and growth, agricultural expansion and agro-industrial pollution have contributed to this decline estimated to be between 3 and 10 percent per year. Alam and Thomson (2001) demonstrated that a host of factors are responsible for the underutilization of fishing areas, including limitation of resources, poor implementation of fisheries laws, the limited spread of fish farming technology, low financial capacities and ineffective production practices.

Shankar et al. (2005) stated that, abstraction of surface water for irrigation poses a serious threat to the sustainability of floodplain fisheries in Bangladesh. This externality imposed on the fishery has important consequences for millions of poor who depend on fishing for their livelihood, and several trends indicate that the problem is likely to 
become worse in the future. The continuing decrease in catching fishes increasingly threatens the livelihoods of more than 12 million fishers in Bangladesh (Monir Hossain et al. 2006). The national catch statistics indicates a catch per unit area (CPUA) for Bangladeshi floodplains of 60-130 kg ha-1 per year (Tapiadon 1983). Other estimates range between ca. 50 and $400 \mathrm{~kg} \mathrm{ha}^{-1}$ per year (Craig et al. 2003).

Therefore, for proper management of fishing unit and for efficient ways of harvesting and to ensure the socioeconomic welfare of the poor fishermen, it is important to find out the productivity of harvesting gears in open access fisheries. This study is an attempt to find out the productivity of different fishing gears that fishermen used in the floodplain beel areas.

\section{Methodology}

\section{Study area}

For this study, data were collected from the beel Sholiamary and beel Gheramary area from Mymensingh Sadar in Bangaldesh. Mymensingh Sadar is situated between $24^{0} 38^{\prime}$ and $24^{\circ} 54^{\prime}$ north latitude and between $90^{\circ} 12^{\prime}$ and $90^{\circ} 30^{\prime}$ 'east latitude having an area of $388.45 \mathrm{sq} \mathrm{km}$ (figure 1). 


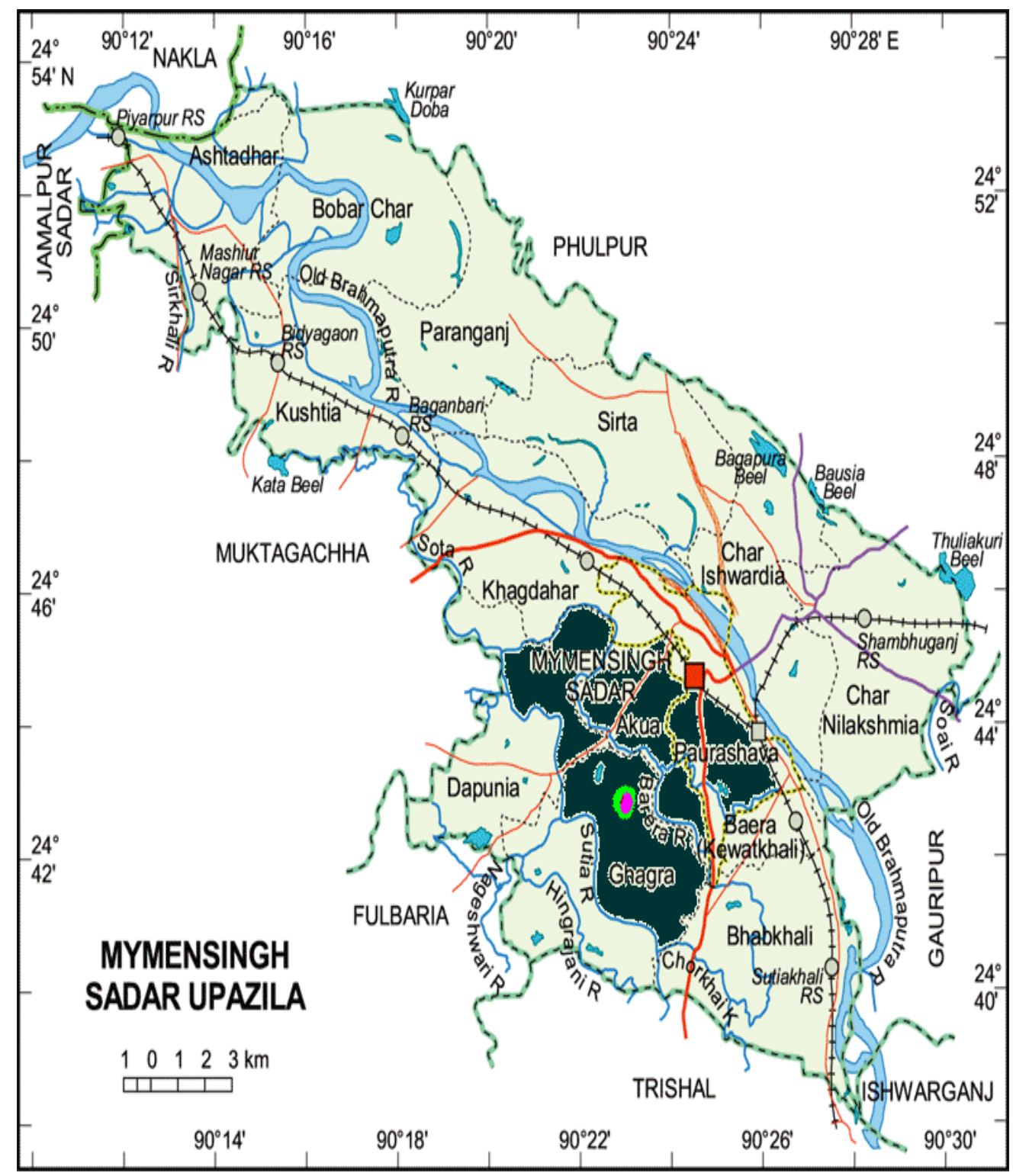

Figure 1: Map of floodplains research area in the Mymensingh Sadar Upazila Source: http://banglapedia.search.com.bd/Maps/MM_0433.GIF

Sholiamary beel is situated beside road side under the village of Bhatibarerpar union of Ghagra upazila of Mymensingh Sadar. It is a semi-closed ${ }^{1} 37$ hectares water body that is privately owned by 106 households. It is connected with Pagairar River under the main river basin of Brahmaputra. Depth of water is on average 1.1 meter and flooding duration is four to five months.

\footnotetext{
${ }^{1}$ Semi-close - permanent lakes whose areas vary depending on the season and with openings where exchange of water occurs (e.g. with a river) and are easily blocked naturally or by fences and nets (Thompson et al.1999).
} 
Gheramary beel is situated under the village of Dariakandi and Tekervita, union of Ghagra upazila of Mymensingh Sadar. It is also a semi-closed water body connected by Garamalla canal to a nearby local river Pagairar, which is ultimately connected with Brahmaputra. This Beel area included 87 ha of privately owned lands and 8 ha of government Khas lands. Farmers grow one rice crop (boro) during January to April and during the rest of the year it remains under water with 2.0-2.5 m water depth during July to October. There is a water control system (sluice gate) of Water Development Board in the canal. There is an earthen road surrounding the floodplain area having several small bridges/culverts (12) in different locations. There are 5 villages located surrounding the beel.

\section{Data Collection}

The data were collected and monitored in respect of fishing activities and social wellbeing of fishers' conditions from July'06 to September'07. All the research data were collected by the researchers themselves with the help of enumerators. For questionnaire interviews, simple stratified random sampling method was followed. The interview with fishermen was arranged at home or in the field.

\section{Models and Variables}

Fishing effort: To calculate fishing effort, the total number of average gear used per day per person (average gear used/day/person) was measured by using the following equation:

Fishing effort $=\frac{\text { Total no. of fishers } \times \text { Average gear used per person } \times \text { Fishing day per month }}{30 \text { day } \mathrm{s}}$

Catch per unit effort (CPUE): To calculate catch per unit effort (CPUE), the number of kilograms of fish caught per unit $(\mathrm{kg} / \mathrm{gear} / \mathrm{hr})$ was measured by using the following equation:

$$
\text { CPUE }=\frac{\text { Total fish chatches by a particular gear }(\text { wt.in } \mathrm{kg})}{\text { No. of particula gear } \times \text { Fishing hours }}
$$

During each survey the fishing effort (the number of fishermen or different gears operated) was recorded at each site. Further, the daily catch of individual fishermen or gears operated at each site was weighed species-wise. Total monthly catch for each site was calculated with:

Monthly catch per site $=N \times \sum_{i, j-1}^{n} \mathrm{~A}_{i, j} \times C P U E_{i, j}$

Where:

$A=$ The average number of fishermen operating a certain gear, observed per day

CPUE $=$ the average daily catch of a fisherman operating a certain gear

$\mathrm{N}=$ the number of days in the month 
Calculation of the monthly catches gave the annual catch per site. The annual yield was obtained by dividing this total annual catch by the maximum extent of the floodplain at each site. To facilitate the analysis, the species were grouped according to the annual catch and were subdivided into other groups.

Data were validated by testing statistical significance of the mean value. Different gears were further tested by using one-way analysis of variance (ANOVA) F-test. To identify significant differences among means, Post Hoc (Scheffe) test was conducted. As the number of sample was not equal for all of the gear, Scheffe method was used for Post Hoc analysis.

To check the linkage between physical and monitory performances with gear efficiency, correlation coefficients were estimated by Pearson's Correlation coefficient method which was also tested for statistical significance at 1\%, 5\%, and $10 \%$ level. The statistical analysis was performed by using SPSS software.

\section{Socioeconomic Characteristics of Fishermen}

In the study areas, the fishermen were categorized into three groups -- i) Full time fishers (FF), those who depend on fishing almost round the year ii) Seasonal or Part time fishers (PF), those who catch fish only during a particular time of the year as source of income and for keeping them engaged in other activities during other time of the year and iii) subsistence fishers (SF), those who catch fish for their household consumption. The number of fishermen varied from one season to another season. The highest number of fishermen was found during monsoon time. The distributions of fishermen by category over the seasons are shown in Table 1.

Table 1: Type of engagement of fishermen at floodplain beels

\begin{tabular}{lrrrr}
\hline \multirow{2}{*}{$\begin{array}{c}\text { Type of } \\
\text { fisherman }\end{array}$} & \multicolumn{2}{c}{ Beel Sholiamary } & \multicolumn{2}{c}{ Beel Gheramary } \\
\cline { 2 - 5 } & $\begin{array}{c}\text { Number of } \\
\text { Fishermen }\end{array}$ & $\begin{array}{c}\text { Average family } \\
\text { size }\end{array}$ & $\begin{array}{c}\text { Number of } \\
\text { Fishermen }\end{array}$ & $\begin{array}{c}\text { Average family } \\
\text { size }\end{array}$ \\
\hline Full Time & $4(13.3)$ & 3.8 & $5(16.7)$ & 4.2 \\
Part-time & $14(46.7)$ & 5.1 & $12(40.0)$ & 5.2 \\
Subsistence & $12(40.0)$ & 4.9 & $13(43.3)$ & 4.9 \\
\hline Total & $30(100)$ & 4.8 & $30(100)$ & 4.9 \\
\hline
\end{tabular}

The data in parentheses indicates percentage of total

Source: Field survey (2007-2008)

Professional fishers are traditionally Hindus, but now Muslims have increased as professional fishermen. The average family size was almost same for both beels (Table 1). The part-time group has large family size compared to other groups, indicating that they are involved in fishing for an extra income to meet the necessity of large family. The average family size of all fishermen was 4.8 persons in beel Sholiamary and 4.9 persons in beel Gheramary. Most of the fishermen are in 30 to 40 years of age (Table 2).

Table 2: Age distribution of fishermen at seasonal floodplain beels 


\begin{tabular}{lrrrrrrrr}
\hline Age & \multicolumn{4}{c}{ Beel Sholiamary } & \multicolumn{5}{c}{ Beel Gheramary } \\
\cline { 2 - 9 } group & FF & PF & SF & Total & FF & PF & SF & Total \\
\hline up to 30 & $1(25)$ & $1(7.1)$ & $3(25)$ & $5(16.7)$ & $2(40)$ & $2(16.7)$ & $1(7.7)$ & $5(16.7)$ \\
31 to 40 & $2(50)$ & $8(57.1)$ & $5(41.7)$ & $15(50)$ & $3(60)$ & $7(58.3)$ & $8(61.5)$ & $18(60)$ \\
41 to 50 & $0(0)$ & $3(21.4)$ & $4(33.3)$ & $7(23.3)$ & $0(0)$ & $3(25)$ & $3(23.1)$ & $6(20)$ \\
above 50 & $1(25)$ & $2(14.3)$ & $0(0)$ & $3(10)$ & $0(0)$ & $0(0)$ & $1(7.7)$ & $1(3.3)$ \\
Total & $4(100)$ & $14(100)$ & $12(100)$ & $30(100)$ & $5(100)$ & $12(100)$ & $13(100)$ & $30(100)$ \\
\hline
\end{tabular}

The data in parentheses indicates percentage of total

Source: Field survey (2007-2008)

The occupations of most of the people in the study area were either agriculture or fishing. Some of them are working as daily labors in the agricultural farm and they do not have agricultural land. Among the respondents, $68 \%$ were mainly farmers. Only 5\% were fulltime fishermen, and $10 \%$ part-time (Table 3). About $36.7 \%$ among all types of fishermen were illiterate and only $8 \%$ fishermen went beyond the secondary school (Table 4).

Table 3: Occupation of the respondent at seasonal floodplain beels

\begin{tabular}{|c|c|c|c|c|c|c|c|c|c|}
\hline \multirow{3}{*}{\multicolumn{2}{|c|}{$\begin{array}{c}\text { Type of } \\
\text { occupations }\end{array}$}} & \multicolumn{4}{|c|}{ Beel Sholiamary } & \multicolumn{4}{|c|}{ Beel Gheramary } \\
\hline & & \multicolumn{3}{|c|}{ Types of fishers } & \multirow{2}{*}{ Total } & \multicolumn{3}{|c|}{ Types of fishers } & \multirow{2}{*}{ Total } \\
\hline & & FF & $\mathrm{PF}$ & $\mathrm{SF}$ & & FF & $\mathrm{PF}$ & $\mathrm{SF}$ & \\
\hline \multirow{4}{*}{$\underbrace{\Xi}_{\Sigma}$} & Agriculture & $0(0)$ & $14(100)$ & $8(66.7)$ & $22(73.3)$ & $0(0)$ & $12(100)$ & $7(53.8)$ & $19(63.3$ \\
\hline & Day labor & $0(0)$ & $0(0)$ & $4(33.3)$ & $4(13.3)$ & $0(0)$ & $0(0)$ & $6(46.2)$ & $6(20)$ \\
\hline & Fishing & $4(100)$ & $0(0)$ & $0(0)$ & $4(13.3)$ & $5(100)$ & $0(0)$ & $0(0)$ & $5(16.7)$ \\
\hline & Total & $4(100)$ & $14(100)$ & $12(100)$ & $30(100)$ & $5(100)$ & $12(100)$ & $13(100)$ & $30(100)$ \\
\hline \multirow{7}{*}{ 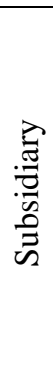 } & Ricksł & $0(0)$ & $0(0)$ & $5(4$ & 5( & $2(40)$ & $0(0)$ & $4(30.8)$ & $6(20)$ \\
\hline & Day labor & $1(25)$ & $0(0)$ & $2(16.7)$ & & $1(20)$ & $0(0)$ & $4(30.8)$ & $5(16.7$ \\
\hline & Service & $0(0)$ & $3(21.4)$ & $0(0)$ & $3(10)$ & $0(0)$ & $5(41.7)$ & $0(0)$ & $5(16.7$ \\
\hline & Business & 0 & 11(78.6) & $1(8.3)$ & $12(50)$ & 0 & $7(58.3)$ & $3(23.1)$ & $10(40)$ \\
\hline & Fish trade & $3(75)$ & 0 & 0 & $3(75)$ & $2(40)$ & 0 & 0 & $2(40)$ \\
\hline & Fishing & $0(0)$ & $0(0)$ & $4(33.3)$ & $4(13.3)$ & $0(0)$ & $0(0)$ & $2(15.4)$ & $2(6.7)$ \\
\hline & Total & $4(100)$ & $14(100)$ & $12(100)$ & $30(100)$ & $5(100)$ & $12(100)$ & $13(100)$ & $30(100)$ \\
\hline
\end{tabular}

The parentheses data indicates percentage of total

Source: Field survey (2007-2008)

Table 4: Literacy level of fishermen at seasonal floodplain beels

\begin{tabular}{lrrrrrrrr}
\hline Education & \multicolumn{4}{c}{ Beel Sholiamary } & \multicolumn{5}{c}{ Beel Gheramary } \\
\cline { 2 - 8 } level & FF & PF & SF & Total & FF & PF & SF & Total \\
\hline Illiterate & $2(50)$ & $2(14.3)$ & $6(50)$ & $10(33.3)$ & $4(80)$ & $2(16.7)$ & $6(46.2)$ & $12(40)$ \\
Primary & $2(50)$ & $3(21.4)$ & $4(33.3)$ & $9(30)$ & $0(0)$ & $2(16.7)$ & $6(46.2)$ & $8(27)$ \\
SSC & $0(0)$ & $6(42.9)$ & $2(16.7)$ & $8(26.7)$ & $1(20)$ & $6(50)$ & $1(7.7)$ & $8(26.7)$ \\
Above SSC & $0(0)$ & $3(21.4)$ & $0(0)$ & $3(10)$ & $0(0)$ & $2(16.7)$ & $0(0)$ & $2(6.7)$ \\
\hline
\end{tabular}




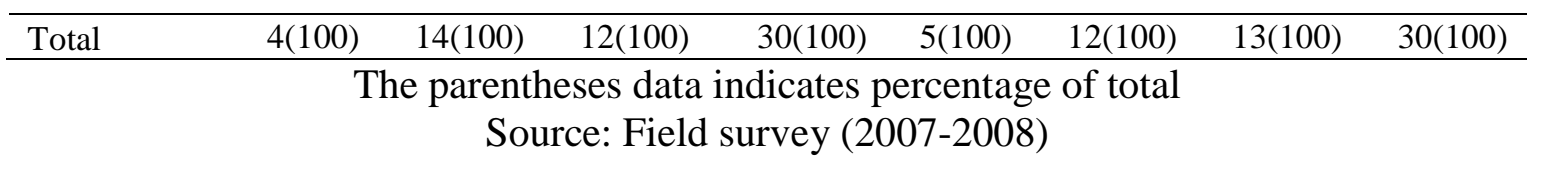

The fishermen had three types of houses in the study areas - 1) Katcha that were made of bamboo and tree leaves with mud floor, 2) Semi-pacca that were made of brick in one part either floor or wall but the roof was in wood or tin, and 3) Pucca were made of brick. All together $62 \%$ of fishermen's houses were katcha, 35\% were semi-paccua, and only $3 \%$ were pucca (Table 5 ).

Table 5: Housing types of fishermen at seasonal floodplain beels

\begin{tabular}{lcccccccc}
\hline \multirow{2}{*}{$\begin{array}{c}\text { Housing } \\
\text { condition }\end{array}$} & \multicolumn{7}{c}{ Beel Sholiamary } \\
\cline { 2 - 8 } & FF & PF & SF & Total & FF & PF & SF & Total \\
\hline Katcha & $4(100)$ & $5(35.7)$ & $12(100)$ & $21(70)$ & $5(100)$ & $4(33.3)$ & $7(53.8)$ & $16(53.3)$ \\
Semi-Pucca & $0(0)$ & $7(50)$ & $0(0)$ & $7(23.3)$ & $0(0)$ & $8(66.7)$ & $6(46.2)$ & $14(46.7)$ \\
Pucca & $0(0)$ & $2(14.3)$ & $0(0)$ & $2(6.7)$ & $0(0)$ & $0(0)$ & $0(0)$ & $0(0)$ \\
\hline Total & $4(100)$ & $14(100)$ & $12(100)$ & $30(100)$ & $5(100)$ & $12(100)$ & $13(100)$ & $30(100)$ \\
\hline \multicolumn{7}{c}{ The parenthen site } \\
\hline
\end{tabular}

The parentheses data indicates percentage of total

Source: Field survey (2007-2008)

The fishermen were considered as healthy when all members in the family were physically and mentally sound. About $85 \%$ of all types of fishers were healthy and only $6 \%$ fishermen were suffering chronic or acute illness (Table 6).

Table 6: Health condition of fishermen at seasonal floodplain beels

\begin{tabular}{lrrrrrrrr}
\hline \multirow{2}{*}{ Health status } & \multicolumn{3}{c}{ Beel Sholiamary } & \multicolumn{5}{c}{ Beel Gheramary } \\
\cline { 2 - 9 } & FF & PF & SF & Total & FF & PF & SF & Total \\
\hline Healthy & $4(100)$ & $12(85.7)$ & $10(83.3)$ & $26(86.7)$ & $3(60)$ & $11(91.7)$ & $11(84.6)$ & $25(83.3)$ \\
Unhealthy & $0(0)$ & $1(7.1)$ & $1(8.3)$ & $2(6.7)$ & $2(40)$ & $1(8.3)$ & $0(0)$ & $3(10)$ \\
Chronically ill & $0(0)$ & $1(7.1)$ & $0(0)$ & $1(3.3)$ & $0(0)$ & $0(0)$ & $1(7.7)$ & $1(3.3)$ \\
Acute illness & $0(0)$ & $0(0)$ & $1(8.3)$ & $1(3.3)$ & $0(0)$ & $0(0)$ & $1(7.7)$ & $1(3.3)$ \\
\hline Total & $4(100)$ & $14(100)$ & $12(100)$ & $30(100)$ & $5(100)$ & $12(100)$ & $13(100)$ & $30(100)$ \\
\hline \multicolumn{8}{c}{ The parentheses data indicates percentage of total } \\
\end{tabular}

All of the fishermen had access to clean and safe drinking water. Though, all fishermen did not have own tube-well, they used pipe water and tube-well water from others. However, the sanitary facilities of the fishermen were very poor. Three types of toilets were available -- i) Water-sealed latrine- that incorporates a water-trap to exclude the movement of insects or smell to and from the toilet, ii) A pit latrine is simply a hole dug in the ground, and iii) pond latrine is constructed over a homestead pond often for integrated fish production. Among all the fishermen, only $68 \%$ of them used the watersealed hygienic sanitation, and the rest were not hygienic (Table 7). 
Table 7: Sanitary facilities of fishermen at seasonal floodplain beels

\begin{tabular}{lrrrrrrrr}
\hline \multirow{2}{*}{ Toilet-type } & \multicolumn{4}{c}{ Beel Sholiamary } & \multicolumn{5}{c}{ Beel Gheramary } \\
\cline { 2 - 9 } & \multicolumn{1}{c}{ FF } & \multicolumn{1}{c}{ PF } & \multicolumn{1}{c}{ Total } & FF & PF & \multicolumn{1}{c}{ SF } & \multicolumn{1}{c}{ Total } \\
\hline Water-sealed & $2(50)$ & $14(100)$ & $6(50)$ & $22(73.3)$ & $0(0)$ & $11(91.7)$ & $8(61.5)$ & $19(63.3)$ \\
Pit latrine & $2(50)$ & $0(0)$ & $5(41.7)$ & $7(23.3)$ & $3(60)$ & $0(0)$ & $0(0)$ & $3(10)$ \\
Pond latrine & $0(0)$ & $0(0)$ & $0(0)$ & $0(0)$ & $0(0)$ & $1(8.3)$ & $1(7.7)$ & $2(6.7)$ \\
Use field & $0(0)$ & $0(0)$ & $1(8.3)$ & $1(3.3)$ & $2(40)$ & $0(0)$ & $4(30.8)$ & $6(20)$ \\
\hline Total & $4(100)$ & $14(100)$ & $12(100)$ & $30(100)$ & $5(100)$ & $12(100)$ & $13(100)$ & $30(100)$ \\
\hline
\end{tabular}

The data in parentheses indicates percentage of total

Source: Field survey (2007-2008)

\section{Productivity Assessment of Fishing Gears}

\section{Fishing Methods and Materials}

Fishing gears are the means that used to catch fish. Various fishing gears were found in the study area which were mostly traditional and some of them were unique for the particular locality. Commonly operated gears were net, trap, and wounding gear. In the monsoon when low lands flooded, usages of all types of gear were increased.

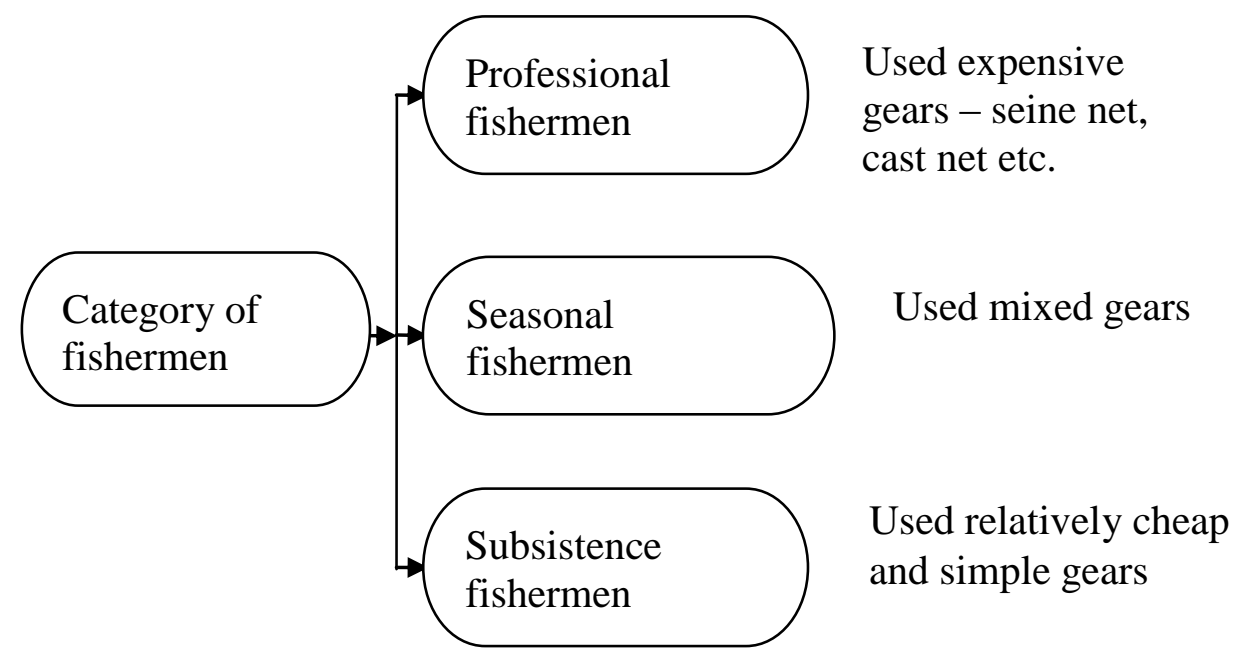

Figure 2: Types of gears used by fishermen

Different types of gears were used by different types of fishermen (Figure 2). Subsistence fishermen caught fish mainly for household consumption using relatively inexpensive and simple gears like bair/ hhulsun, hook (barshi) or push-net. This group includes landless laborers, small farmers, women and children. Bair or Khulsun is a tubular shaped basket like trap which is used for harvesting small fishes. The bamboo sticks were arranged in parallel one after another and were tied with cane materials or wire. Usually bamboo plates were used to make the structure of this gear. There was a unidirectional value at the mouth and single opening at the upper side. It was mainly operated in shallow running water and set against the water current. Fish once entered 
through this valve could not escape. Trapped fish were gathered at the back. After certain period of time, this gear was taken out from water and trapped fishes were collected by opening.

The fishermen who harvested fish using traps like Bair are given in table 9, and those harvested fish by using gears like seine-net, cast-net, lift-net, gill-net, push-net, hooks and long lines (except fishing trap) are given in table 10 . Total $78 \%$ of the fishermen used 1-3 numbers of Bairs and 28\% used Hook for fishing. The lowest number of gears for both sites was the seine-net.

Table 9: Number of Bair used by per fisherman at seasonal floodplain beels

\begin{tabular}{lcccc}
\hline \multicolumn{1}{c}{ Fishermen types } & \multicolumn{2}{c}{ Beel Sholiamary } & \multicolumn{2}{c}{ Beel Gheramary } \\
\cline { 2 - 5 } \multicolumn{1}{c}{ based on Bair used } & Number of Bair & Respondent & Number of Bair & Respondent \\
\hline Type 1 (1-3 traps) & $39(84.7)$ & $25(83.3)$ & $47(74.6)$ & $22(73.3)$ \\
Type 2 (4-6 traps) & $7(15.2)$ & $5(16.6)$ & $16(25.4)$ & $8(26.7)$ \\
\hline Total & $46(100)$ & $30(100)$ & $63(100)$ & $30(100)$ \\
\hline
\end{tabular}

The data in parentheses indicates percentage of total

Source: Field survey (2007-2008)

Table 10: Types of gear used at seasonal floodplain beels

\begin{tabular}{lcccc}
\hline \multirow{2}{*}{ Fishing Gears } & \multicolumn{2}{c}{ Beel Sholiamary } & \multicolumn{2}{c}{ Beel Gheramary } \\
\cline { 2 - 5 } & Number of gear & Respondent & Number of gear & Respondent \\
\hline Seine net (Ber jal) & $3(2)$ & $1(3)$ & $5(3)$ & $1(3)$ \\
Cast net (Jhaki jal) & $20(15)$ & $5(17)$ & $31(16)$ & $5(17)$ \\
Push net (Thela jal) & $24(18)$ & $5(17)$ & $44(23)$ & $7(23)$ \\
Lift net (Dharma jal) & $7(5)$ & $2(7)$ & $13(7)$ & $2(7)$ \\
Gill net (Current jal) & $18(13)$ & $4(13)$ & $30(16)$ & $5(17)$ \\
Hook (Borshi) & $50(37)$ & $10(33)$ & $47(25)$ & $7(23)$ \\
Long line (Tana borshi) & $12(9)$ & $3(10)$ & $21(11)$ & $3(10)$ \\
\hline Total & $134(100)$ & $30(100)$ & $191(100)$ & $30(100)$ \\
\hline
\end{tabular}

The data in parentheses indicates percentage of total

Source: Field survey (2007-2008)

\section{Fishing Effort}

Fishing effort is a useful measure of the ability of a gear to catch a given proportion of the fish stock each year. Effort is standardized by one hour for use in the extrapolation. Fishing efforts of the commonly used gears are presented in Table 11. Among the gears, the lowest and the highest fishing efforts were seine-net and bair, which were recorded for 0.93 gears/day and 45.83 gears/day for Sholiamary beel, and 2.67 gears/day and 83.11 gears/day for Gheramary, respectively.

Table 11: Average fishing efforts observed in a day at seasonal floodplain beels

Name of gear $\quad$ Average number of gear/day




\begin{tabular}{lcc}
\hline & Sholiamary & Gheramary \\
\hline Hook (Borshi) & 30.58 & 44.25 \\
Long line (Tana borshi) & 6.5 & 13.31 \\
Cast net (Jhaki jal) & 5.93 & 9.05 \\
Push net (Thela jal) & 6.4 & 13.98 \\
Lift net (Dharma jal) & 3.17 & 4.55 \\
Gill net (Current jal) & 16.2 & 13.83 \\
Seine net (Ber jal) & 0.93 & 2.67 \\
Bair/ Khulsun & 45.83 & 83.11 \\
\hline Total & 115.54 & 184.75 \\
\hline
\end{tabular}

Source: Field survey (2007-2008)

\section{Fishing Duration}

The use of fishing gears and operation time depends mainly on habitat type, water depth, type of fishermen and abundance of fish. Fishing duration was essential to estimate the fish yields and to keep track of the catch per unit effort (CPUE). It was revealed that the fishers usually increased their operation hours to maintain a satisfactory catch when availability of fishes was low. The average fishing hours of commonly used gears are shown in table 12. In the study area the highest and the lowest fishing duration were recorded in bair and push-net, which were $9.0 \mathrm{hrs} /$ day for Sholiamary and $9.13 \mathrm{hrs} /$ day for Gheramary and $2.3 \mathrm{hrs} /$ day in Sholiamary and $2.64 \mathrm{hrs} /$ day in Gheramary, respectively.

Table 12: Average daily fishing duration at seasonal floodplain beels

\begin{tabular}{lcc}
\hline \multirow{2}{*}{ Name of gear } & \multicolumn{2}{c}{ Fishing duration hrs/day } \\
\cline { 2 - 3 } & Sholiamary & Gheramary \\
\hline Hook (Borshi) & 5.5 & 4.71 \\
Long line (Tana borshi) & 4.5 & 4.50 \\
Cast net (Jhaki jal) & 5.1 & 4.60 \\
Push net (Thela jal) & 2.3 & 2.64 \\
Lift net (Dharma jal) & 5.4 & 5.25 \\
Gill net (Current jal) & 8.3 & 8.70 \\
Seine net (Ber jal) & 4.5 & 4.00 \\
Bair/ Khulsun & 9.00 & 9.133 \\
\hline
\end{tabular}

Source: Field survey (2007-2008)

\section{Catch Per Unit of Effort (CPUE)}

Catch per unit of effort ( $\mathrm{kg} /$ gear/ day) in respect of different fishing gears of the study area are shown in the table 13. Among the gears, the lowest and highest CPUEs were recorded in bair and seine-net that were $0.08 \mathrm{~kg} /$ day and $5.94 \mathrm{~kg} /$ day, respectively, in beel Sholiamary. The lowest and highest CPUEs were recorded in hook and seine-net as 0.07 $\mathrm{kg} / \mathrm{day}$ and $2.82 \mathrm{~kg} / \mathrm{day}$, respectively, in beel Gheramary. In all the gears, seine-net was found to be the most effective gear. 
Table 13: Catch per unit effort (CPUE) of fishes by different gears at seasonal floodplain beels

\begin{tabular}{lcc}
\hline \multirow{2}{*}{ Name of gear } & \multicolumn{2}{c}{ Catch per unit of effort (kg/ gear/ day) } \\
\cline { 2 - 3 } & Sholiamary & Gheramary \\
\hline Hook (Borshi) & 0.09 & 0.12 \\
Long line (Tana borshi) & 0.66 & 0.73 \\
Cast net (Jhaki jal) & 0.82 & 1.51 \\
Push net (Thela jal) & 0.52 & 0.73 \\
Lift net (Dharma jal) & 0.46 & 0.76 \\
Gill net (Current jal) & 0.56 & 0.85 \\
Seine net (Ber jal) & 5.94 & 2.82 \\
Bair/ Khulsun & 0.08 & 0.07 \\
\hline
\end{tabular}

Source: Field survey (2007-2008)

\section{Monitory Income from Fishing Gears}

Monthly income of fishermen was found highest by using gill-net (TK1885) and bair (TK209) for beel Sholiamary whereas at beel Gheramary the highest was for long-line (TK1036) and lowest was for Bair (TK237) (Table 14).

Table 14: Average monthly income of fishermen by gears at seasonal floodplain beels

\begin{tabular}{lcc}
\hline & \multicolumn{2}{c}{ Average Monthly income (TK) } \\
\cline { 2 - 3 } Name of gear & Sholiamary & Gheramary \\
\hline Hook (Borshi) & 246 & 248 \\
Long line (Tana borshi) & 1499 & 1036 \\
Cast net (Jhaki jal) & 1061 & 988 \\
Push net (Thela jal) & 461 & 521 \\
Lift net (Dharma jal) & 507 & 596 \\
Gill net (Current jal) & 1885 & 877 \\
Seine net (Ber jal) & 1483 & 611 \\
Bair/ Khulsun & 209 & 237 \\
\hline \multicolumn{1}{c}{ Total } & 13285 & 7861 \\
\hline
\end{tabular}

Source: Field survey (2007-2008)

\section{Physical and Economic Productivity of Fishing Gears}

The physical productivity of fishing gears in terms of daily catches differed significantly among the gear users given in the table 15 . The seine-net differed significantly with all other gears and vice versa. Hooks also differed with cast-net and gill-net and vice versa. The economic productivity of fishing gears based on average monthly income also followed the same pattern. The economic productivity of fishing gear based on total seasonal income also did not differ with the pattern of average monthly income as number of fishing month(s) per season did not differ significantly. However, economic productivity of hook and gill-net did not differ significantly for total seasonal income but differed based on average monthly income. The fishing days per month significantly differed only for the lift-net with hook, gill-net and push-net. The fishing gears were not 
different significantly based on the social and demographic data such as number of household members, educations, etc.

Table 15: Descriptive Statistics of Gear Usage

\begin{tabular}{|c|c|c|c|c|c|c|c|c|}
\hline \multicolumn{2}{|c|}{ Gear } & $\mathrm{N}$ & Mean & $\begin{array}{r}\text { Std. } \\
\text { Deviation }\end{array}$ & Min. & Max. & $\begin{array}{r}\text { Post Hoc Sig. } \\
\text { (Scheffe) }\end{array}$ & $\begin{array}{r}\text { ANOVA } \\
\text { F-test } \\
\end{array}$ \\
\hline \multirow{6}{*}{$\begin{array}{l}\text { Average } \\
\text { monthly } \\
\text { income }\end{array}$} & Hooks & 13 & 527 & 312 & 256 & 1222 & $\mathrm{~b}^{*}, \mathrm{c}^{*}, \mathrm{~d} \sim$ & \multirow{6}{*}{$35.7 *$} \\
\hline & Seine net & 9 & 3827 & 1273 & 2042 & 5618 & $a^{*}, c^{*}, d^{*}, e^{*}, f^{*}$ & \\
\hline & Cast net & 10 & 1638 & 504 & 994 & 2740 & $a^{*}, b^{*}$ & \\
\hline & Gill net & 8 & 1399 & 550 & 689 & 2417 & $a \sim, b *$ & \\
\hline & Push net & 16 & 1003 & 300 & 578 & 1786 & $b^{*}$ & \\
\hline & Lift net & 4 & 916 & 306 & 638 & 1353 & $b^{*}$ & \\
\hline \multirow{6}{*}{$\begin{array}{l}\text { Total } \\
\text { seasonal } \\
\text { income } \\
\text { from } \\
\text { fishing }\end{array}$} & Hooks & 13 & 1776 & 844 & 768 & 3666 & $b^{*}, c^{\wedge}$ & \multirow{6}{*}{$28.6^{*}$} \\
\hline & Seine net & 9 & 16522 & 7049 & 8168 & 28088 & $a^{*}, c^{*}, d^{*}, e^{*}, f^{*}$ & \\
\hline & Cast net & 10 & 6653 & 1944 & 2981 & 9188 & $a^{\wedge}, b^{*}$ & \\
\hline & Gill net & 8 & 5224 & 2520 & 2066 & 9667 & $b^{*}$ & \\
\hline & Push net & 16 & 4002 & 1112 & 2120 & 5395 & $\mathrm{~b}^{*}$ & \\
\hline & Lift net & 4 & 3119 & 751 & 2479 & 4060 & $b^{*}$ & \\
\hline \multirow{6}{*}{$\begin{array}{l}\text { Daily } \\
\text { catches }\end{array}$} & Hooks & 13 & 0.67 & 0.37 & 0.27 & 1.49 & $b^{*}, c^{*}, d^{\wedge}$ & \multirow{6}{*}{$40.3^{*}$} \\
\hline & Seine net & 9 & 4.45 & 1.36 & 2.66 & 6.24 & $a^{*}, c^{*}, d^{*}, e^{*}, f^{*}$ & \\
\hline & Cast net & 10 & 1.92 & 0.31 & 1.47 & 2.38 & $a^{*}, b^{*}$ & \\
\hline & Gill net & 8 & 1.80 & 0.71 & 1.15 & 3.16 & $a^{\wedge}, b^{*}$ & \\
\hline & Push net & 16 & 1.29 & 0.42 & 0.60 & 2.21 & $b^{*}$ & \\
\hline & Lift net & 4 & 0.79 & 0.16 & 0.70 & 1.03 & $b^{*}$ & \\
\hline \multirow{6}{*}{$\begin{array}{l}\text { Number } \\
\text { of month } \\
\text { per season }\end{array}$} & Hooks & 13 & 3.54 & 0.52 & 3.00 & 4.00 & & \multirow{6}{*}{2.2} \\
\hline & Seine net & 9 & 4.22 & 0.44 & 4.00 & 5.00 & & \\
\hline & Cast net & 10 & 4.10 & 0.74 & 3.00 & 5.00 & & \\
\hline & Gill net & 8 & 3.63 & 0.52 & 3.00 & 4.00 & & \\
\hline & Push net & 16 & 4.06 & 0.85 & 3.00 & 5.00 & & \\
\hline & Lift net & 4 & 3.50 & 0.58 & 3.00 & 4.00 & & \\
\hline \multirow{6}{*}{$\begin{array}{l}\text { Fishing } \\
\text { days per } \\
\text { month }\end{array}$} & Hooks & 13 & 10.79 & 2.80 & 5.00 & 16.00 & $f \sim$ & \multirow{6}{*}{$2.9^{\wedge}$} \\
\hline & Seine net & 9 & 11.22 & 0.78 & 10.00 & 12.80 & & \\
\hline & Cast net & 10 & 11.41 & 2.20 & 9.00 & 16.00 & & \\
\hline & Gill net & 8 & 10.50 & 1.77 & 8.00 & 13.00 & $f \sim$ & \\
\hline & Push net & 16 & 10.63 & 1.81 & 6.67 & 13.60 & $f^{\wedge}$ & \\
\hline & Lift net & 4 & 14.67 & 1.89 & 12.00 & 16.00 & $\mathrm{a} \sim, \mathrm{d} \sim, \mathrm{e}^{\wedge}$ & \\
\hline
\end{tabular}

$*, \wedge, \sim$ denotes significance at the $1 \%, 5 \%$, and $10 \%$ level, respectively; ${ }^{a}$ denotes -mean data differs significantly from Hooks, ${ }^{\mathrm{b}}$ denotes- mean data differs significantly from Seine net, ${ }^{\mathrm{c}}$ denotes -mean data differs significantly from Cast net, ${ }^{\mathrm{d}}$ denotes - mean data differs significantly from Gill net, ${ }^{\mathrm{e}}$ denotes - mean data differs significantly from Push net, ${ }^{f}$ denotes - mean data differs significantly from Lift net

Some of the fishing gears showed significant relationship with physical and economic issues of productivity measurement (Table 16). The seine-net gear showed significant correlation with types of beel types. Here beel was a binary data where beel Gheramary was coded 0 and beel Sholiamary as 1 . In beel Sholiamary, there were some carp fingerling were released by the Department of Fisheries (DoF) thus the gear performance also differed based on beel types. Seine-net also showed significant relationship with physical productivity measurement unit - daily catch amount, and 
economic productivity measurement unit - average monthly income and total seasonal income. As the catch of the gear was so high and planned, it did not have any significant relationship with fishing days or number of month(s) used for fishing in a season.

Table 16: Correlation among the variables

\begin{tabular}{|c|c|c|c|c|c|c|c|c|}
\hline & Beel & $\begin{array}{c}\text { Average } \\
\text { Monthly } \\
\text { income }\end{array}$ & $\begin{array}{c}\text { Total } \\
\text { Seasonal } \\
\text { income } \\
\text { from } \\
\text { fishing }\end{array}$ & $\begin{array}{l}\text { Number } \\
\text { of month } \\
\text { fishing } \\
\text { per } \\
\text { season }\end{array}$ & $\begin{array}{c}\text { Fishing } \\
\text { days per } \\
\text { month }\end{array}$ & $\begin{array}{l}\text { Daily } \\
\text { Catches }\end{array}$ & $\begin{array}{l}\text { Household } \\
\text { members }\end{array}$ & $\begin{array}{c}\text { Year of } \\
\text { Schooling }\end{array}$ \\
\hline $\begin{array}{l}\text { Average Monthly } \\
\text { income }\end{array}$ & $0.25 \sim$ & & & & & & & \\
\hline $\begin{array}{l}\text { Total Seasonal } \\
\text { income from fishing }\end{array}$ & .122 & $.979^{*}$ & & & & & & \\
\hline $\begin{array}{l}\text { Number of month } \\
\text { fishing per season }\end{array}$ & $-.413^{*}$ & $.255^{\wedge}$ & $.400^{*}$ & & & & & \\
\hline $\begin{array}{l}\text { Fishing days per } \\
\text { month }\end{array}$ & $-.268^{\wedge}$ & .136 & .129 & .144 & & & & \\
\hline Daily Catches & $.325^{\wedge}$ & $.978^{*}$ & $.953^{*}$ & $0.23 \sim$ & -.040 & & & \\
\hline $\begin{array}{l}\text { Household total } \\
\text { members }\end{array}$ & -.020 & .091 & .098 & -.013 & .092 & .077 & & \\
\hline Year of Education & .037 & .084 & .104 & -.066 & -.238 & .114 & -.056 & \\
\hline Hooks & -.202 & $-.415^{*}$ & $-.396^{*}$ & $-.265^{\wedge}$ & -.083 & $-.423^{*}$ & -.030 & .097 \\
\hline Seine net & $.233 \sim$ & $.821^{*}$ & $.803^{*}$ & .208 & .016 & $.825^{*}$ & .060 & .030 \\
\hline Cast net & .000 & .060 & .057 & .141 & .057 & .051 & .009 & -.228 \\
\hline Gill net & -.098 & -.025 & -.051 & -.148 & -.115 & .009 & .002 & .159 \\
\hline Push net & .075 & $-.237 \sim$ & -.211 & .158 & -.140 & $-.213 \sim$ & -.086 & -.051 \\
\hline Lift net & .000 & -.125 & -.136 & -.149 & $.434^{*}$ & -.192 & .100 & .011 \\
\hline
\end{tabular}

The hook was the most unproductive gear both in terms of physical and economic measures of efficiency (Table 16). It showed significant negative relationship with the daily catch amount, monthly and total seasonal income, and number of month of fishing. Push-net also showed statistically and significantly unproductive gear for daily catches and monthly income. Lift-net only showed statistically significant positive relationship with fishing days per month. However, none of the gears had any relationship with the social and demographic data such as number of household members, educations, etc.

Amount of daily catches determined the income from fishing. Therefore, amount of daily catches showed statistically significant positive relationships with total seasonal income, monthly income and number of fishing month(s). Total seasonal income was highly correlated with average income. Average monthly income was statistically significantly related with number of fishing month(s). Due to the release of extra carp fingerlings in one beel, the efficiency differed based on beel types and it showed significant relationships with monthly income, number of fishing months, fishing days, and daily catches of fish. 


\section{Conclusions}

There were three types of fishermen - part-time, full-time, and subsistence fishermen who were engaged in fishing during monsoon in the seasonal floodplain beels. The average family sizes of the fishermen were recorded 4.8 persons and 4.9 persons in beel Sholiamary and beel Gheramary respectively. The highest numbers of fishermen were engaged for part-time fishing. Among all fishermen, $33.3 \%$ were illiterate in the beel Sholiamary and $40 \%$ in beel Gheramay. The housing conditions and sanitary conditions of the fishermen were not at satisfactory level. However, they had access to safe water.

The fishermen used different types of gears for catching fish from the beels. Among these fishing gears in the study area, five gears were fishing nets, one fishing trap and two wounding gears. The fishing effort and fishing duration varied with the type of gear. The highest fishing effort and fishing duration were recorded for bair, and lowest fishing effort was for seine-net and lowest fishing duration was for push-net. The seinenet was the most productive gear and the bair was the least productive gear. The highest catch per unit of effort (CPUE) was recorded as $5.95 \mathrm{~kg} /$ gear/ day and $2.82 \mathrm{~kg} /$ gear/ day for seine-net in Sholiamary and Gheramary, respectively. The average monthly highest income was found for beel Sholiamary as Taka (TK) 1885 by using the gill-net and lowest TK209 for the bair, and for beel Gheramary highest was TK1036 for long-line and lowest TK237 for bair.

The physical productivity of gears in terms of daily catches and economic productivity of gears in terms of income from fishing differed significantly, especially seine-net differed significantly from all other gears, and hooks differed from cast-net and gill-net and vice versa. After the bair, the hook was the most unproductive gear which showed significant negative relationship with the daily catch amount, monthly and total seasonal income, and number of month(s) of fishing.

The fishing gears were not different significantly based on the social and demographic data and none of the gears had any relationship with the social and demographic data such as number of household members, educations, etc. Amount of daily catches that determined the income from fishing showed statistically significant positive relationships with total seasonal income, monthly income and number of fishing months. The availability of fishes in the two beels differed due to extra carp fingerlings released in one beel. The types of beels showed significant relationships with monthly income, number of fishing months, fishing days, and daily catches of fish.

\section{References}

Ahmed, M., Capistrano D. \& Hossain, M. 1992. Redirecting benefits to genuine fishers: Bangladesh's new fisheries management policy. Naga, ICLARM Quarterly. 15(4): 31-34.

Alam, M. F. \& Thomson, K. J. 2001. Current constraints and future possibilities for Bangladesh fisheries. Food Policy. 26 (3): 297-313. 
Craig, J.F., Halls, A.S., Barr, J.J.F. and Beand, C.W., 2003. The Bangladesh floodplain fisheries. Fisheries Research, 66: 271-286.

DOF 2008. Sankalan, Matsha Sampod Unyan Avizan 2008. Department of Fisheries (DOF), Fisheries and livestock Ministry, Dhaka, Bangladesh.

DOF. 1990. Manual of Catch Assessment Survey (1987-1988), Fisheries resources survey system. Department of Fisheries (DoF), Government of the People's Republic of Bangladesh, Fisheries and livestock Ministry, Dhaka, Bangladesh

DoF. 2004. Fish Fortnight' 2004. Department of Fisheries (DOF), Ministry of Fisheries and Livestock, Dhaka, Bangladesh.

Haque, M.M. 1995. Fisheries sector at a glance in Bangladesh. Fish Fortnight 1995 (In Bengali), Department of Fisheries, Dhaka, Bangladesh. 94 pp.

Mazid M.A. \& Hossain M. S. 1995. Development of fish resources in floodplains. FRI Publication No. 12, Fisheries Research Institute, Mymensingh, Bangladesh, pp. 29-31.

Minkin, S.F., Rahman, M.M. \& Halder, S. 1997. Fish biodiversity, human nutrition and environmental restoration in Bangladesh. In: Tsai, C., Ali, M.Y. (Eds.), Open Water Fisheries of Bangladesh. University Press, Dhaka, pp. 75-88.

Monir Hossain, M, Islam, M.A., Ridgway, S., \& Matsuishi, T. 2006. Management of inland open water fisheries resources of Bangladesh: Issues and options. Fisheries Research. 180 (1-3): 275-284.

MPO. 1986. National Water Plan. Sector Analysis. Master Plan Organization (MPO) Technical Report No. 1. Dhaka.

Sadeque S.Z. 1992. Capture fisheries and other common property resources in the floodplains of Bangladesh. J. Sci. Stu. Dhaka. 55, 20-34.

Shankar B., Halls A. \& Barr J. 2005. The Effects of Surface Water Abstraction for Rice Irrigation on Floodplain Fish Production in Bangladesh', Int. J. Water. 3 (1), 6183.

Siddiqui, K. 1989. Licencing vs. leasing system for government owned fisheries (jalmahals) in Bangladesh. In M. Aguero, S. Huq, A. Rahman \& M.Ahmed (eds) Inland Fisheries Management in Bangladesh. Department of Fisheries Dhaka, Bangladesh; Bangladesh Center for Advanced Studies; and ICLARM, Manila, Philippines, pp73-82.

Tapiadon D.D. 1983. Small-scale water conservancy for agro-aquaculture the IndoPacific region. Indo-Pacific Fisheries Commission (IPFC) Summary Report and Selected Papers Resented at the IPDC Workshop on Inland Fisheries for Planners, Manila The Philippines, 2-6 August 1983. Petr, ed. FAO, Rome Italy no. 288, pp. 111-118.

Thompson P.M., Sultana P., Islam M.N., Kabir M.M., Hossain M.M. \& Kabir M.S. 1999. An assessment of co-management arrangements developed by the Community Based Fisheries Management Project in Bangladesh, Paper Presented at the International Workshop on Fisheries Co-management, 23-28 August 1999, Penang, Malaysia. 